\title{
КАНАДСКИЕ ЧТЕНИЯ
}

(Москва, 31 мая 2017 г., Москва, 30 мая 2018 г.)

\section{Л.М. Троицкая}

Статья информирует о Четвертых и Пятых научных сессиях в рамках Канадских чтениях памяти Вадима Александровича Коленеко (1943-2011). Четвертые Канадские чтения (Москва, 31 мая 2017 г.) были посвящены 150-летию образования Канадской Конфедерации. Пятые Канадские чтения (Москва, 30 мая 2018 г.) были приурочены к 75-летию со дня рождения Вадима Александровича Коленеко. Заседания были организованы Центром североамериканских исследований Института всеобщей истории РАН и Российским обществом изучения Канады.

Ключевые слова: научная сессия, Канадские чтения, образование Канадской Конфедерации, 75-летие со дня рождения Вадима Александровича Коленеко

The article informs about the Forth and Fifth scientific sessions within the limits of Canadian Readings in memoriam of Vadim A. Koleneko (1943-2011). The Forth Canadian Readings (Moscow, May 31, 2017) was devoted to the $150^{\text {th }}$ anniversary of Canadian Confederation. The Fifth Canadian Readings (Moscow, May 30, 2018) was coincided with the $75^{\text {th }}$ birthday of Vadim A. Koleneko. The sessions were held by the Center for North American Studies of the Russian Academy of Sciences and Russian Association for Canadian Studies.

Key words: scientific session, Canadian Readings, foundation of Canadian Confederation, $75^{\text {th }}$ birthday of Vadim A. Koleneko

тало доброй традицией проводить силами Центра североамериканских исследований (ЦСАИ) Отдела региональных исследований Института всеобщей истории РАН (ИВИ РАН) и Российского общества изучения Канады (РОИК) специальных научных сессий - Канадских чтений. Обычно они проходят в конце мая и посвящены памяти одного из крупнейших российских канадоведов доктора исторических наук, ведущего научного сотрудника Вадима Александровича Коленеко (1943-2011). В 31 мая 2017 г. в Москве прошли Четвертые Канадские 
чтения, приуроченные к 150-летию образования Канадской Конфедерации. С докладами и сообщениями выступили ведущие отечественные канадоведы - историки, экономисты, литературоведы, филологи, политологи - из академических институтов, а также представители некоторых крупнейших научно-образовательных центров Москвы и С.Петербурга. Был обсужден широкий круг вопросов, связанных с историей, современным состоянием и культурой Канады. Тексты ряда докладов и сообщений Е.Г. Комковой, Ю.Г. Акимова, Т.Р. Кузьминой, Е.В. Исаевой, а также информация Л.М. Троицкой о Четвертых Канадских чтениях были опубликованы в «Канадском ежегоднике» (М., 2017. Вып. 21) ${ }^{1}$.

Кроме упомянутых докладчиков, на заседании с докладом на тему «Партийный системы Канады на федеральном и провинциальном уровнях: общее и особенное» выступил А.Н. Комаров (д.и.н., проф. Российского государственного гуманитарного университета, отв. редактор «Канадского ежегодника»), проанализировавший функционирование партийных систем Канады на федеральном и провинциальном уровнях. Он сделал вывод, что на общенациональном уровне в стране существует двухпартийная система, а на региональном уровне это не наблюдается и там возможна многопартийность. Кроме того, социальная и региональная база, сформированная для партийных систем канадских провинций, теснейшим образом связана с историческими, экономическими и национальными особенностями их развития.

Л.А. Немова (к.э.н., зав. сектором Института Соединенных Штатов Америки и Канады РАН [ИСКРАН]) представила доклад «Позиции Канады в глобальной экономике», в котором выявила определенное сходство России и Канады по масштабам и по структуре их экономик. Кроме того, она отметила, что под влиянием процессов глобализации в Канаде произошли важные перемены, что основные показатели экономики этой страны в последние два года оказались в Канаде худшими за 60 лет (исключая периоды рецессий), что для возврата к более сбалансированному развитию Канады потребуется 10-15 лет.

\footnotetext{
${ }^{1}$ Комкова Е.Г. Премьер-министры Канады и президенты США: экскурс в историю отношений // Канадский ежегодник. М., 2017. Вып. 21. С. 49-65; Акимов Ю.Г. Развитие квебекской парадипломатии во второй половине 1980-х - начале 1990-х гг. // Там же. С. 143-165; Кузьмина T.P. Новый министр иностранных дел Канады: новый курс? // Там же. С. 179-199; Исаева Е.В. Квебекский роман о земле (1846-1945) // Там же. С. 300-317; Троицкая Л.М. Научная сессия Центра североамериканских исследований ИВИ РАН и РОИК на тему «Канадские чтения» памяти д.и.н. Вадима Александровича Коленеко (1943-2011): К 150-летию образования Канадской Конфедерации (Москва, 31 мая 2017 г.) // Там же. С. 346-359.
} 
Сообщение И.А. Аггеевой (к.и.н., ст. научн. сотр. Института всеобщей истории РАН [ИВИ РАН]) «Судьба доктора: советский след в биографии Нормана Бетьюна» было посвящено малоизвестному эпизоду биографии этого выдающегося канадского хирурга и изобретателя. И.А. Агеева рассказала об основных вехах биографии симпатизировавшего СССР и коммунистическим идеям, участника гражданской войны в Испании, антифашиста, интернационалиста и новатора медицины Н. Бетьюна и особо остановилась на его деятельности в Китае в 1938-1939 гг., где он трагически погиб в 1939 г.

Темой выступления О.А. Федосюк (литературовед, переводчик, член правления РОИК) была «Проза англоязычной Канады 1970-х гг. - Золотой век в истории канадской литературы». Докладчик отметила, что хотя художественная литература не всегда непосредственно связана с политическими событиями, тем не менее, юбилей Канадской Конфедерации позволяет взглянуть на англоязычную канадскую прозу с исторической дистанции и выделить 1970-е гг. как наиболее интересный и плодотворный период в ее развитии. О.А. Федосюк проследила, как большой интерес к истории Канады, стремление к национальному самоопределению и самоидентификации, а также желание преодолеть колониальность в сочетании с поисками новых художественных возможностей позволили таким писателям, как Маргарет Лоренс, Маргарет Этвуд, Робертсон Дейвис, Мэриан Энгел, Джек Ходжинс, создать уникальный для страны пласт художественной прозы.

В сообщении «Гендерные битвы в геймерском сообществе Канады» Т.Ю. Забелиной (к.и.н., доцент, АНО ВО Московский гуманитарный университет) было отмечено, что в 2014 г. в канадских и других англоязычных медиа разразился шумный скандал, получивший название «геймергейт» (по аналогии с Уотергейтом). Он начался с расследований в игровой журналистике, однако быстро охватил темы женоненавистничества в культуре компьютерных игр, а также дискриминации женщин-разработчиц. Т.Ю. Забелина заявила, что практически вся ведущая пресса встала на их защиту.

Широкий круг проблем истории, современного положения и культуры Канады обсуждался в ходе юбилейных, Пятых «Канадских чтений: история и современность», ЦСАИ ИВИ РАН и РОИК, посвященных 75-летию со дня рождения д.и.н. Вадима Александровича Коленеко (Москва, 30 мая 2018 г.). Были заслушаны 7 докладов и 7 сообщений.

Заседание открылось докладом А.Н. Комарова (д.и.н., проф. кафедры всеобщей истории Российского государственного гуманитарного университета, отв. редактор «Канадского ежегодника») на тему «Но- 
вая демократическая партия Канады в борьбе за власть на парламентских выборах 1984, 1988 и 2011 гг.», в котором была предпринята попытка рассмотреть участие в указанных выше избирательных кампаниях Новой демократической партии Канады во главе с ее лидерами Э. Бродбентом и Дж. Лейтоном., проследил эволюцию этой партии в 1980-х - начале 2010-х гг. Докладчик подчеркнул, что именно при Э. Бродбенте и Дж. Лейтоне партия достигла своего наибольшего расцвета.

Темой доклада Д.А. Володина (к.и.н., заведующий отделом Канады ИСКРАН) является «Канада и Договор о запрещении ядерного оружия». Выступающий рассмотрел место Канады при осуществлении внешнеполитической деятельности касательно вопросов ядерного нераспространения и разоружения, заметив, что с начала $1990-$ х гг. интерес официальной Оттавы к этой теме неуклонно снижался. При этом отмечалось, что всплеск интереса в Канаде к вопросам, касающимся ядерного оружия, совпал, одной стороны, со сменой правящей партии (октябрь 2015 г.), а с другой - активизацией усилий международного сообщества за запрещение ядерного оружия. При правительстве Дж. Трюдо резко возросло внимание Канады к ядерной проблематике. По мнению Д.А. Володина, фактически эта страна играла на стороне США, которые призывали своих союзников выступить против заключения Договора о запрещении ядерного оружия. Будучи не в состоянии помешать принятию этого Договора, Канада серьезно подорвала свой многолетний имидж борца за ядерное разоружение.

Л.А. Немова (к.э.Н., зав. сектором ИСКРАН) выступила с докладом на тему «"Меж двух огней”: Канада в ситуации торгово-экономического конфликта между США и Китаем». В нем были охарактеризованы позиции противников и сторонников значительного расширения двустороннего экономического взаимодействия. Показано, что противоречивость и непоследовательность заявлений и действий правительства Канады во многом объясняется влиянием «американского фактора». Это стало особенно очевидным в условиях обострения торгово-экономического конфликта между США и Китаем в 2018 г.

В центре доклада И.А. Аггеевой (к.и.н., ст. научн. сотр. ИВИ РАН) было «Формирование “канадских ценностей”: роль третьих партий в национальной истории». Отмечалось, что новое восприятие корневых ценностных ориентиров состоит в трактовке закрепленных правом и традицией идей как важного ресурса национальной идентичности и стабильности. Помимо свода известных либерально-демократических и гуманитарных принципов, к ним относят приверженность многообразию, открытость, солидарность, коллективизм, сопричастность 
и вовлеченность (inclusiveness) индивида в дела государства и сообщества, неприятие социального, гендерного насилия, экстремизма, упорядоченность свободы и законопослушность и т.д. Они формировались исторически при участии ряда деятелей «третьих» партий.

Один из ведущих российских специалистов по истории Квебека Ю.Г. Акимов (д.и.н., проф. кафедры американских исследований факультета международных отношений СПбГУ) представил доклад «Квебекская парадипломатия и второй референдум о суверенитете Квебека», в котором были рассмотрены международная деятельность Квебека в период подготовки второго референдума о суверенитете провинции (30 октября 1995 г.), отношения этой канадской провинции со своими главными партнерами - США и Францией, предпринимавшиеся федеральным правительством «контрмеры» для нейтрализации усилий Квебека на международной арене.

С докладом «Канадская дипломатия при правительстве Дж. Трюдо: формы, методы, оценки» выступила Е.В. Исраелян (к.и.н., вед. научн. сотр. ИСКРАН). Она рассмотрела следующие вопросы: Каковы успехи и неудачи канадской дипломатии при правительстве Дж. Трюдо? Какие методы и приемы она использует? В чем ее инновационный потенциал? Е.Г. Комкова (д.э.н., зав. сектором политических проблем Канады ИСКРАН) также проявила интерес к позиции и действиям премьер-министра Дж. Трюдо, а также премьер-министра С. Харпера относительно торговых отношений Канады с США. Этой проблематике был посвящен ее доклад «Лозунг свободной торговли с США во взглядах и политических действиях канадских премьер-министров Дж. Трюдо и С. Харпера».

Весьма разнообразны по тематике были сообщения, с которыми выступили в ходе Пятых Канадских чтений. Так, Т.Р. Кузьмина (к. филол. н., ведущий научный сотрудник, руководитель Центра развития и инноваций ИСКРАН, президент РОИК) в сообщении «Деятельность правительства Канады и Международного совета по канадским исследованиям в мире и Канаде: проблемы и достижения» рассмотрела этапы развития исследований Канады в мире, роль канадских научных центров по установлению связей с партнерами в мире, политику канадского правительства, в частности кабинета С. Харпера, проводившуюся в разные периоды, относительно распространения знаний о Канаде как инструмента формирования имиджа страны за ее пределами. Т.Р. Кузьмина рассмотрела разработку кабинетом Харпера программ продвижения канадского бренда и закрытие программ поддержки канадских исследований в мире и проанализировала влияние этой политики на современное состояние канадских исследований в мире и России. Деятельность Международной ассоциации по изуче- 
нию Квебека с момента ее создания в 1997 г. и по 2017 г. проанализирована Е.В. Исаевой (к. филол. н., проф. РГГУ, директор российскоканадского учебно-научного центра «Москва-Квебек» РГГУ) в сообщении «Международная ассоциация по изучению Квебек: выход из кризиса».

Т.А. Щукина (ст. научн. сотр. ИСКРАН) выступила с сообщением на тему «Современные тенденции в культурной политике Канады», проанализировав новую инициативу в области культурной политики, получившую название «Креативная Канада» (Creative Canada), с которой в сентябре 2017 г. выступило либеральное правительство Канады.

Некоторые новые явления в общественной жизни Канады исследовала Т.Ю. Забелина (к.и.н., доцент Московского гуманитарного университета). Темой ее выступления - «Канада говорит: “МеТоо”». Это относится к общественному движению против сексуального насилия и домогательств, которое зародилось в США в 2000-х гг. Широкую известность оно приобрело осенью 2017 г., когда в сети стартовала акция с хэштегом \#МеТоо. Участницы движения были названы коллективной персоной года по версии американского журнала «Тіте». В декабpe 2017 г. в Канаде появилась своя версия движения - \#AfterMeToo.

Важная проблема в истории славянской иммиграции в Канаду затронута в сообщении К.В. Минковой (к.и.н., ст. препод. кафедры американских исследований СПбГУ) «К вопросу о переходах славянских иммигрантов-униатов в Канаде в православие (конец XIX - начало XX в.)». Докладчик отметил, что в 1897 г. волна переходов славянских иммигрантов-униатов в православие, прокатившаяся по ряду штатов США, достигла Канады, где тот процесс прошел более быстро и гладко.

О.А. Федосюк (литературовед, переводчик) посвятила сообщение анализу некоторых аспектов творчества выдающейся канадской писательницы М. Этвуд «Канадская версия древнегреческого мифа - "Пенелопиада" Маргарет Этвуд». Рассмотрено, как, полемизируя с Гомером и используя такие постмодернистские приемы, как ирония и игра, писательница создает неожиданную версию сказания об Одиссее и Пенелопе. Ставя в центр повествования Пенелопу и ее служанок, акцентируя их роль, Этвуд дает канадскую трактовку древнегреческого мифа.

Завершились Пятые Канадское чтения презентацией К.С. Романова (к. культурологии, доцент факультета иностранных языков и регионоведения МГУ им. М.В. Ломоносова) цикла «Культура франкоязычной Канады как части франкофонии: опыт преподавания учебного курса в Московском университете» как составной части лекционного 
курса «Культура современной Франции и стран франкофонии». В том цикле К.С. Романов представил свою методику преподавания франкоканадской проблематики в рамках культурологии; основные темы, затрагиваемые в курсе; источники и методы оценивания работы студентов. 